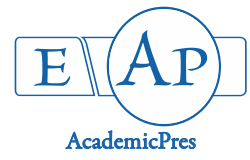

\title{
Prevalence of Group A Rotavirus, Some Risk Factors and Clinical Signs of the Infection in Children Under Five Years in Yobe State, Nigeria
}

\author{
John GARBA ${ }^{1}$, Olufemi O. FALEKE ${ }^{2}$, Abdullahi A. MAGAJI ${ }^{2}$, \\ Bello R. ALKALI ${ }^{3}$, Innocent O. NWANKWO ${ }^{4 *}$, Asabe A. DZIKWI ${ }^{5}$ \\ ${ }^{1}$ Veterinary Council of Nigeria, NVRIVOM, Jos, Nigeria; grbjhn@yahoo.com \\ ${ }^{2} U$ smanu Danfodiyo University, Faculty of Veterinary Medicine, Department of Veterinary Public Health, Sokoto, \\ Nigeria; oofaleke@gmail.com;magaji1965@yahoo.com \\ ${ }^{3}$ Usmanu Danfodiyo University, Faculty of Veterinary Medicine, Department of Veterinary Veterinary Microbiology, Sokoto, \\ Nigeria;balkali@yahoo.co.uk \\ ${ }^{4}$ University of Nigeria, Nsukka, Faculty of Veterinary Medicine, Department of Veterinary Public Health and Preventive Medicine, Enugu, \\ Nigeria; innocent.nwankwo@unn.edu.ng ( ${ }^{*}$ corresponding author) \\ ${ }^{5}$ University of Jos, Faculty of Veterinary Medicine, Department of Veterinary Public Health and Preventive Medicine, Jos, \\ Nigeria; asabezik@yahoo.com
}

\begin{abstract}
Diarrhoea in children is caused by variety of disease agent including Rotavirus. With the increase in child mortality rate in the state which has been associated with lack of adequate hygiene's especially for those displaced from their homes, Rotavirus infection may have often been misdiagnosed since the zoonotic potentials, prevalence in children, associated risk factors and clinical signs have not been fully elucidated in Nigeria. These were determined in children who were presented for treatments for gastroenteritis in Government Hospital in Yobe State, Nigeria between the period of April 2014-May 2016 using structured questionnaire and ELISA kit. Rotavirus was detected in $18.1 \%(30 / 166)$ of the patients, $18.4 \%(16 / 87)$ and $17.7 \%$ $(14 / 79)$ were in males and females respectively, while $17.7 \%$ (17/96), 15.4\% (8/52), 27.8\% (5/18) were for ages $(<1-24,25-48$ and 49-60) months old respectively. Rotavirus infection was significantly associated $(\mathrm{P}<0.05)$ with age, day-care, signs of vomiting, mother's educational status, type of stool and duration, unlike in type of food, drinking water, presence of fever, animal contact and father's occupation $(\mathrm{P}>0.05)$. Rotavirus is in circulation in the state and the clinical signs and some of the risk factors were significantly associated with the infection, thus will aid in early diagnosis, prevention and control of the virus spread in Nigeria.
\end{abstract}

Keywords: patients; prevalence; risk factors; Rotavirus; Yobe State; Nigeria

\section{Introduction}

Diarrheal diseases account for $17 \%$ of the 10.4 million deaths in children under 5 years old worldwide (Tate et al., 2016; WHO, 2016). Rotavirus strains have been identified globally as one of the three major pathogenic causes of diarrhea in children and the young of different animal species (Waggie et al., 2010). They are non-enveloped viruses, measuring about $75 \mathrm{~nm}$ in diameter and belong to the genus Rotavirus and family Reoviridae (Estes et al., 2007). The viruses are distinguished into eight sero groups (A-H) based on host antibodies to the VP 6 protein group antigen of which Rotavirus group $A$ is the most prevalent group in both humans and animals (Ghosh et al., 2007; Waggie et al., 2010). The infection is known to be transmitted via the fecal-oral route and by contact with contaminated fomites (Waggie et al., 2010). The infection manifest as mild to severe diarrhea in the young mammals and animal with other clinical signs like vomiting, depression, anorexia, dehydration and acidosis (Sherchand and Haruki, 2004). Persistent diarrhea do not only impaired digestive and absorptive processes of nutrients, it can leads to dehydration and death especially in children (Sherchand and Haruki, 2004; WHO, 2009).

The infection has been reported in both developed and developing countries (Koopmans and Brown, 1999; Mwenda et al., 2010). In developing countries, the virus has 
accounted for $15-34 \%$ of all death of children less than 5 years old (Ada et al., 2002). Furthermore, as at 2013, it has been estimated that about 233, 000 deaths of children under the age of five years were cause by Rotavirus disease, $22 \%$ of the death occurred in India while $49 \%$ is accounted for in four countries of India, Nigeria, Pakistan and Democratic Republic of Congo (Tate et al., 2016). In Nigeria, the infection has been reported as endemic in children under the age of five in significant rates (Aminu et al., 2008; Pennap and Umoh, 2010). In the study area, the infection may have been under reported or mis- diagnosed as limited data exist on the infection in the study area in contrast to the abundant risk factors associated with the infection which include little or no observance to good hygienic practices, lack of pit toilet, lack of access to potable water, co habitation with animals and poor environmental sanitation among others (Sergio and Ponce de Leon, 2009). Thus, in the present study are presented the prevalence of Rotavirus group A infection and the significance of the associated risk factors and clinical signs in children presented with gastroenteritis at government hospitals in the state will aid in prevention, early diagnosis and control of infection which spread.

\section{Materials and Methods}

This is a hospital-based study conducted at five government hospitals which were randomly selected one each from the local government that made up the five agricultural zones of Yobe state area with latitudes $10^{\circ} 30^{\prime}$ and $13^{\circ} 25^{\prime} \mathrm{N}$ and longitudes $9^{\circ} 35^{\prime}$ and $12^{\circ} 30^{\prime} \mathrm{E}$ of the Northern hemisphere (MAWR, 2008; Orunonye, 2009). Multi-stage sampling method was used (Putt et al., 1987). Children presented with gastroenteritis at Government Hospitals or Health Centers were grouped according to age $(<1-24,25-48$ and 49-60) months old and sampled with consent of parents.

\section{Sample size estimation}

The minimum sample size was calculated using the formula: $n=z^{2} \times p(1-p) \div d^{2}$ (Thrusfield, 1997). Where; $\mathrm{n}=$ sample size, $\mathrm{Z}=$ score for confidence interval $(95 \%$ confidence coefficient was taken at 1.96 score), $\mathrm{P}=$ Known prevalence $\mathrm{d}=5 \%$ desired precision.

A minimum sample size of 160 was calculated using a known prevalence (P) of $11.8 \%$ (Ada et al., 2001).

\section{Ethical consideration and approval}

This study was approved by Yobe State Ministry of Health and Human Services, Yobe State.

\section{Sample collection and storage}

About $2 \mathrm{gm}$ fresh stool passed out by each participant were collected by scooping three aseptic spatula in a labelled capped sterilized plastic container, then transported cold to the laboratory and stored at $4{ }^{\circ} \mathrm{C}$ for 48 hours prior to making a $10 \%$ suspension in phosphate buffered saline, $\mathrm{pH}$ 7.2 after centrifugation at $8000 \mathrm{rpm}$ for 3 minutes and further preserved at $-20{ }^{\circ} \mathrm{C}$ until processed as described (Junaidu et al., 2011).
Sample preparation

Up to $0.1 \mathrm{~g}$ or $300 \mu \mathrm{l}$ faecal suspensions was added to 1 $\mathrm{ml}$ of distilled water which was mix and vortexed vigorously for a minute. Into a fresh labelled tubed, was transferred 1 $\mathrm{ml}$ supernatant of each sample for ELISA test.

\section{Detection of group A Rotavirus}

A commercially available ELISA kit (Automation, CA., U.S.A.) was used. Briefly, to each test well of the micro titre plates, $100 \mu \mathrm{l}$ aliquots of prepared faecal samples was added and the positive and negative controls, then the plates were covered with aluminium foil and incubated at $24^{\circ} \mathrm{C}$ for 1 hour. The plates were washed three times (first round) with washing solution. Upon the completion of the first round washing, $100 \mu \mathrm{l}$ of the conjugate solution (provided in the kit) was dispensed into each well, incubated at $24^{\circ} \mathrm{C}$ for 1 hour and washed as before. After the second round of washing the plates 3 times, $100 \mu \mathrm{l}$ of chromogen solution (provided in the kit) was added to each well on the plate and incubated at $24^{\circ} \mathrm{C}$ away from light for 10 minutes. Thereafter, $50 \mu \mathrm{l}$ of stop solution (provided in the kit) was added to each well. The reading of the optical densities was recorded immediately after stop solution was added by means of a micro plate spectrophotometer (Optical ivy men system) with a $450 \mathrm{~nm}$ filter. The reading was calculated and interpreted according to manufacturer's instruction.

\section{Data analyses}

Data were analyzed for percentages/ proportions in frequency tables and charts. Logistic regression was used to obtain p-values, odds ratios (OR) and 95\% confidence interval (CI).

\section{Results}

The Table 1 below shows the prevalence of Rotavirus infection in children in Yobe state, Nigeria. Out of a total of 166 faecal samples, 30 (18\%) were positive for group A Rotavirus. Ninety six, 52 and 18 children were aged $(<1-24$, $25-60$ and 49-60) months respectively, and (17.7\%), 8 (15.4\%) and 5 (27.8\%) were positive for Rotavirus group A in the same order. Furthermore, the prevalence rates in males and females were $18.4 \%$ and $1417.7 \%$ respectively (Table 1).

Among the children's parents, 82, 48 and 36 of them had below secondary, secondary and above secondary level of education respectively, out of which $21(25.6 \%), 3$ (6.3\%) and $6(16.7 \%)$ of their children were positive for group A Rotavirus in the same order (Table 2). Furthermore, 8 (21.6\%), 9 (18.4\%), $5(16.1 \%)$ and 8 $(16.3 \%)$ were the prevalence rates in children from 37,49 , 31 and 49 parents respectively, whose occupation were farming, business, civil service and other jobs in the same order (Table 2).

Table 3 below shows the prevalence of Rotavirus infection in children in relation to their water source and types of food. Out of the 166 children, 29, 123 and 14 uses water that were sourced from well, borehole and river/dam respectively, out of which 5 (17.2\%), 23 (18.7\%) and 2 (14.3\%) were positive for Rotavirus A in the same order. 
334

Out of 8 children that drink boiled water and 158 that do not boil their water, 1 (12.5\%) and 29 (18.4\%) were positive for Rotavirus A respectively. The study further revealed 4 (23.5\%), $9(17.0 \%), 17(18.1 \%)$ and none as positive out of $17,53,94$ and 2 children that fed on breast milk, both breast milk and solid food, solid food only, and others respectively. The virus was also discovered in 25 $(18.1 \%)$ and $5(18.0 \%)$ out of 138 and 28 children respectively whose food were prepared by their mothers and nannies respectively (Table 3 ).

Table 4 shows, the prevalence of Rotavirus infection in children in relation to attendance at day care and contact with animals in Yobe state, Nigeria. Out of 24 children that attends day care and 142 that do not attend day care, 3 (12.5\%) and 8 (14.8\%) were positive for Rotavirus infection respectively. Out of 112 children that had contact with animals and 54 without contact, $22(19.6 \%)$ and 8 (14.8\%) were positive for Rotavirus infection respectively. Furthermore, the prevalence was higher in those that had contact with ruminant than those with poultry and pets (Table 4).

Rotavirus infection was more in children that passed watery faeces than those that passed semi solid faeces with $28.3 \%$ and $15.3 \%$ rates respectively while the maximum prevalence with regards to the duration of diarrhoea was 64.3\% at 3-4 days. Furthermore, those that experienced vomiting and fever had $38.3 \%$ and $23.4 \%$ prevalence rates respectively which were higher than $6.6 \%$ and $7.3 \%$ in those without vomiting and fever respectively (Table 5). Among the five agricultural zones where the samples were sourced from, the least prevalence rate $(8.6 \%)$ was in Nguru while the highest rate (25\%) was in Gashua (Fig. 1).

Table 1. Prevalence of Rotavirus group A infection in diarrheic children in relation to age and sex in Yobe state, Nigeria

\begin{tabular}{|c|c|c|c|c|c|c|}
\hline Parameter & Number tested & No. positive (\%) & No. negative (\%) & P-value & OR & $95 \% \mathrm{CI}$ \\
\hline \multicolumn{7}{|l|}{ Age } \\
\hline $0-24$ & 96 & $17(17.7)$ & $79(83.3)$ & & & \\
\hline $25-48$ & 52 & $8(15.4)$ & $44(84.6)$ & 0.020 & 0.511 & $0.290-0.900$ \\
\hline $49-60$ & 18 & $5(27.8)$ & $13(72.2)$ & & & \\
\hline \multicolumn{7}{|l|}{ Sex } \\
\hline Male & 87 & $16(18.4)$ & $71(81.6)$ & 0.755 & 0.846 & $0.296-2.420$ \\
\hline Female & 79 & $14(17.7)$ & $65(72.3)$ & & & \\
\hline Total & 166 & $30(18.1)$ & $136(82.9)$ & & & \\
\hline
\end{tabular}

Note: Age in months, $\mathrm{OR}=$ odds ratio, $\mathrm{CI}=$ Confidence interval.

Table 2. Prevalence of Rotavirus group A infection in diarrheic children in relation to parents' educational status and occupation in Yobe state, Nigeria

\begin{tabular}{|c|c|c|c|c|c|c|}
\hline Parameter & Number tested & No. positive (\%) & No. negative (\%) & P-value & OR & $95 \% \mathrm{CI}$ \\
\hline \multicolumn{7}{|c|}{ Parents' educational status } \\
\hline $\mathrm{B} / \mathrm{Sec}$ & 82 & $21(25.6)$ & $61(65.4)$ & 0.020 & 2.02 & $1.030-4.010$ \\
\hline Sec. & 48 & $3(6.3)$ & $45(93.7)$ & & & \\
\hline $\mathrm{A} / \mathrm{sec}$ & 36 & $6(16.7)$ & $30(83.3)$ & & & \\
\hline \multicolumn{7}{|c|}{ Parents' occupation } \\
\hline Farming & 37 & $8(21.6)$ & $29(78.4)$ & & & \\
\hline Business & 49 & $9(18.4)$ & $40(81.6)$ & 0.009 & 4.725 & $1.471-15.174$ \\
\hline Civil Ser. & 31 & $5(16.1)$ & $26(83.9)$ & & & \\
\hline Other Jobs & 49 & $8(16.3)$ & $41(83.7)$ & & & \\
\hline
\end{tabular}

Table 3. Prevalence of Rotavirus infection in diarrheic children in relation to water sources and food types in Yobe state, Nigeria

\begin{tabular}{|c|c|c|c|c|c|c|}
\hline Parameter & Number tested & No. positive (\%) & No. negative (\%) & P-value & OR & $95 \% \mathrm{CI}$ \\
\hline \multicolumn{7}{|l|}{ Source of water } \\
\hline Well & 29 & $5(17.2)$ & $24(82.8)$ & & & \\
\hline Tap/Borehole & 123 & $23(18.7)$ & $100(81.3)$ & 0.907 & 0.954 & $0.434-2.099$ \\
\hline Dam/River & 14 & $2(14.3)$ & $12(85.7)$ & & & \\
\hline \multicolumn{7}{|l|}{ Boiling water } \\
\hline Yes & 8 & $1(12.5)$ & $7(87.5)$ & 0.143 & 2.164 & $0.746-6.276$ \\
\hline No & 158 & $29(18.4)$ & $129(81.6)$ & & & \\
\hline \multicolumn{7}{|l|}{ Type of food } \\
\hline $\mathrm{BMO}$ & 17 & $4(23.5)$ & $13(76.5)$ & & & \\
\hline $\mathrm{BM}$ and SLF & 53 & $9(17.0)$ & $44(83.0)$ & & & \\
\hline SLF & 94 & $17(18.1)$ & $77(81.9)$ & 0.571 & 1.430 & $0.415-4.927$ \\
\hline Others & 2 & $0(0)$ & $2(100)$ & & & \\
\hline \multicolumn{7}{|c|}{ Person who usually prepares child's food } \\
\hline Mother & 138 & $25(18.1)$ & $113(81.9)$ & 0.911 & 0.951 & $0.391-2.310$ \\
\hline Nanny/Others & 28 & $5(18.0)$ & $23(82.0)$ & & & \\
\hline
\end{tabular}


Table 4. Prevalence of Rotavirus infection in diarrheic children in relation to attendance at day care and contact with animals in Yobe state, Nigeria

\begin{tabular}{|c|c|c|c|c|c|c|}
\hline Parameter & Number tested & No positive (\%) & No Negative (\%) & P-value & OR & $95 \% \mathrm{CI}$ \\
\hline \multicolumn{7}{|c|}{ Day care centre attendance } \\
\hline Yes & 24 & $3(12.5)$ & $21(87.5)$ & 0.00 & 0.02 & $0.006-$ \\
\hline No & 142 & $27(19.0)$ & $115(81.0)$ & 0 & 1 & 0.077 \\
\hline \multicolumn{7}{|c|}{ Contact with domestic animals } \\
\hline Yes & 112 & $22(19.6)$ & $90(80.4)$ & 0.45 & 1.406 & $0.581-3.401$ \\
\hline No & 54 & $8(14.8)$ & $46(85.2)$ & & & \\
\hline \multicolumn{7}{|c|}{ Type of animal in contact } \\
\hline Ruminants & 80 & $17(21.3)$ & $63(78.7)$ & & & \\
\hline Poultry & 16 & $3(18.8)$ & $13(81.2)$ & 0.310 & 0.854 & $0.629-1.159$ \\
\hline Pets & 17 & $2(11.8)$ & $15(88.2)$ & & & \\
\hline None & 53 & $8(15.1)$ & $45(4.9)$ & & & \\
\hline \multicolumn{7}{|c|}{ Frequency of contact } \\
\hline Often & 73 & $13(17.8)$ & $60(82.8)$ & & & \\
\hline Rarely & 21 & $4(19.0)$ & $17(81.0)$ & 0.785 & 0.943 & $0.617-1.439$ \\
\hline Never & 72 & $13(18.1)$ & $59(81.9)$ & & & \\
\hline
\end{tabular}

Table 5. Prevalence of Rotavirus group A infection in diarrheic children in relation to some clinical signs in Yobe state, Nigeria

\begin{tabular}{|c|c|c|c|c|c|c|}
\hline Parameter & Number tested & No. positive (\%) & No. negative (\%) & P-value & OR & $95 \% \mathrm{CI}$ \\
\hline \multicolumn{7}{|l|}{ Stool type } \\
\hline Watery & 53 & $15(28.3)$ & $38(71.7)$ & 0.038 & 0.419 & $0.184-0.953$ \\
\hline Semi-solid & 98 & $15(15.3)$ & $83(84.7)$ & & & \\
\hline Solid & 15 & $0(0)$ & $15(100)$ & & & \\
\hline \multicolumn{7}{|c|}{ Duration of diarrhoea } \\
\hline 1-2 days & 108 & $5(4.6)$ & $103(5.4)$ & & & \\
\hline $2-3$ days & 40 & $16(40.0)$ & $24(60.0)$ & & & \\
\hline 3-4 days & 14 & $9(64.3)$ & $5(36.7)$ & 0.000 & 4.987 & $2.745-9.092$ \\
\hline $5-7+$ days & 4 & $0(0)$ & $4(100)$ & & & \\
\hline \multicolumn{7}{|c|}{ Sign of vomiting } \\
\hline Yes & 60 & $23(38.3)$ & $37(62.7)$ & 0.000 & 21.125 & $6.860-65.054$ \\
\hline No & 106 & $7(6.6)$ & $99(93.4)$ & & & \\
\hline \multicolumn{7}{|l|}{ Sign of fever } \\
\hline Yes & 111 & $26(23.4)$ & $85(76.6)$ & 0.193 & 0.584 & $0.260-1.312$ \\
\hline No & 55 & $4(7.3)$ & $51(92.7)$ & & & \\
\hline
\end{tabular}

$\mathrm{OR}=$ odds ratio, $\mathrm{CI}=$ Confidence interval.

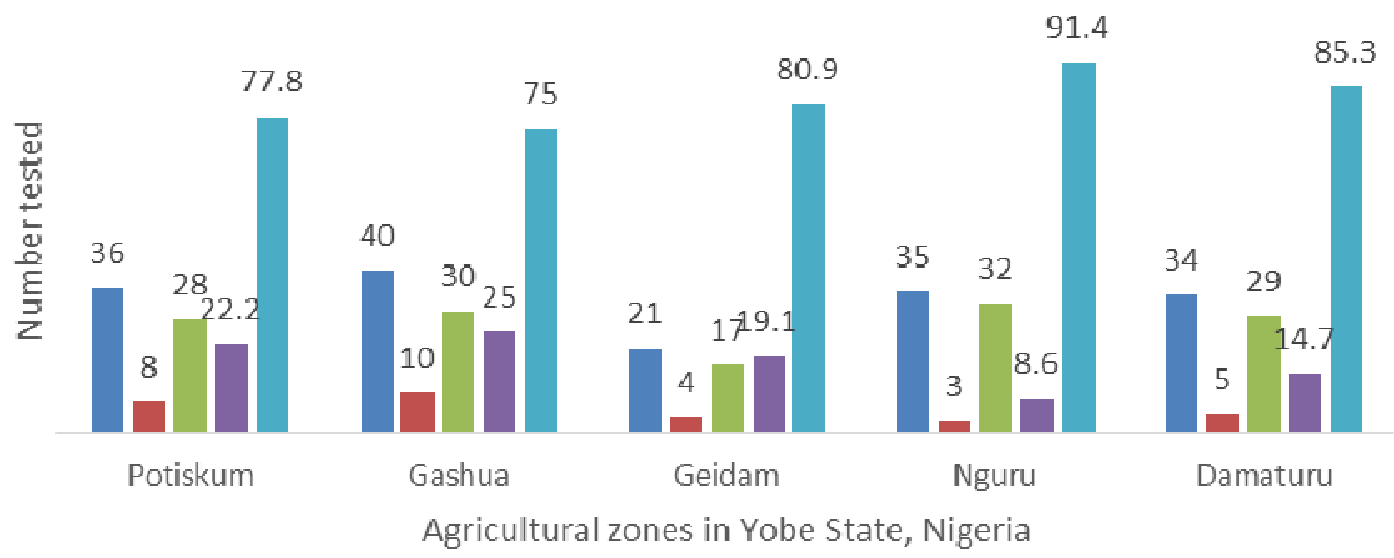

No tested $\quad$ No.positive $\quad$ No.negative $\quad \%$ positive $\quad \%$ negative

Fig. 1. Prevalence of Rotavirus infection among children in the five agricultural zones of Yobe state, Nigeria 
336

\section{Discussion}

Studies from other parts of the world have reported varied rates of Rotavirus prevalence as well as in Nigeria where significant rates have been reported among the states. In respect to this, the prevalence in Yobe state was investigated (Tate et al., 2016). The prevalence of Rotaviruses in the study area has confirmed the virus as a common pathogens circulating in children below 5 years in Nigeria (Aminu et al., 2014; Alkali et al., 2015). The prevalence rate in the study was similar to $18.0 \%$ in Northwestern Nigeria and $17.3 \%$ recorded each in Zaria and Jos, Northern Nigeria (Pennap et al., 2000; Steele et al., 2002; Aminu et al., 2014). The result was also in agreement with $19.2 \%$ recorded in Benin City in Southern Nigeria (Iyoha and Abioudun, 2015). However, it disagreed with the high rates of $22.3 \%, 25.5 \%$ and $25.8 \%$ reported in Kwara, Lagos and Sokoto states of Nigeria (Ogunsanya et al., 1994; Odimayo et al., 2008; Alkali et al., 2015) and lower rates of $12.4 \%, 15.7 \%$ and $13.8 \%$, reported in Lagos, Kano and Zaria respectively (Audu et al., 2002; Pennap and Umoh 2010).

The result in this study further contradicts the higher values of 39-52\% estimated for African region (Nakawesi $e t$ al., 2010). The observed discrepancy in prevalence rates could be attributed to geographical location, season of sample collection and method of screening used (CDC, 2008). Rotavirus group A infection was detected in all age groups of children studied but with higher prevalence rate among children between 49-60 months of age group which disagreed with the findings that reported higher prevalence in infants (0-3 months) and young children (6-24 months) of age (Aminu et al., 2014; Alkali et al., 2015). This could be due to behavioural activities of children at this age, as they have disposition of independence and tend to play outside the house possibly in a contaminated environment.

It has been reported that boys were twice susceptible and likely to be admitted to hospitals than girls in incidences of three illnesses namely; pneumonia, diarrheal and malaria as reported (Nair et al., 2015). The detection of higher prevalence in male $18.4 \%$ than females with $17.7 \%$ in the study was not different from observation in previous studies (Aminu et al., 2014). Furthermore, studies have reported no statistical significant difference in Rotavirus prevalence between male and female children in Zaria and Sokoto (Pennap and Umoh, 2010; Alkali et al., 2015).

The general observation that Rotavirus is often found predominantly within families closed communities, daycare centres and paediatrics wards was supported by our findings, even though that majority of the children in the study were not taken to day care centres, the statistical analysis indicated significant association between Rotavirus infection and attending day care centre (CDC, 2008; White et al., 2008). Earlier findings have reported the recovery of Rotavirus particles from naturally contaminated and frequently handled surfaces in day- care centres (Keswick et al., 1983). The role of human hands as a vehicle for the spread of rotavirus particles has also been reported (Ansari et al., 1988; Keswick et al., 1983).

The detection of high prevalence of Rotavirus in watery stool $28.3 \%$, semi-solid stool $15.3 \%$ and solid stool $0 \%$ was in agreement with reports that blood tinged diarrhoea are rare in Rotavirus infection (Pennap and Umoh, 2010; Aminu et al., 2014). However, it is believed that bloody watery stool in Rotavirus infections could arise from mixed infection with other pathogens such as Shigella and E. coli especially in developing areas where transmission of enteric pathogens and co - infection could be high as a result of poor sanitation, low immunity, lack of access to treatment, imbalanced diet and poor nutrition (Ansari et al., 1988).

Earlier studies have shown that Rotavirus infection is associated with severe to moderate diarrhoea episodes, vomiting and fever which often led to severe dehydration in babies and young children (Offit and Clark, 2000; Bass and Dorsey, 2004; WHO, 2016). In this study, the association between vomiting and Rotavirus infection was statistically significant and the odds of the infection for children who had history of vomiting were 21 times more likely than the odds of the infection for children who had no history of vomiting with a true population effect between $93.1 \%$ and $34.9 \%(\mathrm{P}=0.000$; $\mathrm{OR}=21.13$; $95 \% \mathrm{CI}=6.860-65.054)$. Also, in this study high prevalence rate was between 3-4 days duration of vomiting which was in contrary to previous observations that recorded higher prevalence in 1-2 days of diarrhoea (Pennap and Umoh, 2010). The difference observed in this study is probably due to differences in household hygiene and food preparation practices or individual child's nutritional status. In this study, severity of dehydration was not determined, but other studies carried out in Nigeria indicated significant association between Rotavirus infection and dehydration (Pennap and Umoh, 2010; Aminu et al., 2014).

The result of analysis on the type of food fed to children in relation to Rotavirus infection showed a higher prevalence of the Rotavirus infection among children fed with breast milk only (23.5\%) followed by those children fed with solid food (18.1\%) while a lower prevalence was recorded among children fed with breast milk and solid food (17.0\%). Statistical analysis showed no significant association between Rotavirus infections with type of food children were fed with. But, the odds of the infection for children who were fed breast milk and solid food are 1.4 times more likely than the odds of the infection for children who were fed breast milk only with a true population effect between $95.9 \%$ and $50.7 \%(\mathrm{P}=0.571$; OR $=1.430 ; 95 \%$ $\mathrm{CI}=0.415-4.927)$. The findings in this study are similar to the findings that reported highest prevalence of Rotavirus infection among children who were exclusively fed with breast milk (Pennap and Umoh, 2010). Their result suggested that breast feeding only may not protect the child against Rotavirus infections (Lamberti et al., 2011). The result obtained in this study was in disagreement with a study that reported that exclusive breast feeding particularly in infant children offers some protection against severe Rotavirus infections (Aminu et al., 2014). Other studies have reported that exclusive breast feeding provides an intense and continuous high level protection against Rotavirus gastroenteritis among children (Quigley et al., 2006; Lamberti et al., 2011) but the protective effect in infants and children age $<1-6$ months was stronger than in older children because most mothers have Rotavirus antibodies from previous infection that is passed transplacental, protecting the infants (Aminu et al., 2014). 
However, there is the need for further investigation on the role of feeding regimen in the occurrence of Rotavirus infection.

The prevalence of Rotavirus infection in relation to the persons that usually prepared children's food showed that of all the positive samples, majority of the cases (83.3\%), mothers were responsible for the preparation of the child's food followed by the nannies/any other person (16.7\%). The result in this study is in contrast to the findings which reported that majority of cases $(56.4 \%)$ of Rotavirus infection in children are due to food usually prepared by nannies or any other person while (24.4\%) were for food prepared by mothers (Alkali et al., 2015). The disparity observed in this study may be due to variation in socioeconomic factors or cultural practices between metropolitan residents of Sokoto and those residents in urban and rural communities of Yobe (Dennehy, 2000).

From the study, the result indicated no significant statistical association between Rotavirus infection and the source of drinking water. However, the odds of the infection for children whose drinking water is tap/bore hole are almost equal to the odds of infection for children whose source of water are well, dam/river with a true population effect between $95.6 \%$ and $79.0 \%(\mathrm{P}=0.907$; $\mathrm{OR}=0.954$ 95\% $\mathrm{CI}=4.342-2.099)$. The prevalence reported in this study is contrary to the prevalence obtained in Sokoto (Alkali, 2015) that reported more than $46.2 \%$ of the Rotavirus infection cases in children whose major source of water was neither tap nor well water and $(23.6 \%)$ in children whose major source of water was tap water. The contrast identified in this study may have arisen due to the fact that in most communities in Yobe water is sourced from communal water sources where the commodity is usually collected in containers and hauled in wheel barrows by water vendors or by member(s) of a family who may lack good personal hygiene practices thereby aiding the spread of the infection.

The result of analysis on boiling drinking water for the child in relation to Rotavirus infection indicated that majority of the parents (18.4\%) did not boil water given to the children and that only (12.5\%) indicated that water given to the children was boiled which gave the proportion of Rotavirus infection among children whose drinking water was not boiled against those whose drinking water was boiled $97.5 \%$ and $3.3 \%$ respectively. The difference in terms of association was not significant which is in agreement with earlier findings that reported that type of drinking water of the child had no statistical significant association with Rotavirus prevalence (Pennap and Umoh, 2010).

Most of the residents of Yobe State rear animals such as ruminants and chickens or keep pets such as cats or dogs in the house. In this study, Rotavirus infection in children based on child's contact with animals showed no significant statistical association with Rotavirus infection. However, the odds of the infection for children who had contact with animals are 1.4 times more likely than the odds of the infection for children who had no contact with animals with a true population effect between $94.1 \%$ and $65.9 \%$ $(\mathrm{P}=0.450 ; \mathrm{OR}=1.41 ; 95 \% \mathrm{CI}=0.581-3.401)$. The reason for this may probably due to common life styles among children at that age and sample size. The findings in this study are similar to the findings of (Yilgwani and Okolo, 2012), (Karambu et al., 2013) and (Bahartha and Alezzi, 2015) that reported no significant association between contact with animals and diarrheal diseases in Jos, (Nigeria), Igambe, (Kenya) and Al-Mukalla, (Yemen) respectively.

The result on educational status of parents indicate that children whose parents' educational levels were below secondary school had the highest prevalence $25.6 \%$ (21/82) while children whose parents had secondary level of education had the lowest prevalence 6.2\% (3/48). Statistical analysis revealed significant association between Rotavirus infection and educational status of child's mother. The odds of infection in children whose mother education status was below secondary school are 2 times more likely than the odds of infection for children whose mother's education status was secondary school and above with a true population effect between $89.7 \%$ and $59.9 \%(\mathrm{P}=0.020$; $\mathrm{OR}=2.02 ; 95 \% \mathrm{CI}=1.030-4.010)$. This may be explained by the fact that highly educated parents may have acquired more skills, practice and knowledge to protect their children from likely exposure to Rotavirus infection. Further, it's likely that children whose parents are highly educated might belong to the working class who may need to take their children to day care centers. The findings in this study however goes against the findings reported in (Aminu et al., 2008) and (Junaidu et al., 2011) which all reported children whose parents had primary education had the highest prevalence while those children whose parents had informal education had the least.

Rotavirus infection was detected in children below the age of five in all the five agricultural zones of Yobe State, thus points to the urgent need for awareness creation and implementation of Rotavirus control measures in the State. In this study, the observed varied rates of infection across zones may be due to difference in levels of immunity of children in the respective locations since geographical location and environmental factors are among main factors that influence difference in Rotavirus prevalence (CDC, 2008).

\section{Conclusions}

Rotavirus infection has been detected in children below 5 years old with diarrhoea in Yobe State, Nigeria with a prevalence rate of $18.1 \%$ which has been revealed to be significantly associated with age groups, attending of daycare centre, signs of vomiting, type of stool and duration of diarrhoea in addition to the educational level of mothers in the state, The findings will aid in prompt diagnosis, prevention and control of the infection in children in Yobe state, Nigeria.

\section{Acknowledgements}

The authors are grateful to the management and staff of the Department of Veterinary Public Health and Preventive Medicine and Veterinary Microbiology laboratories, Usmanu Danfodiyo University Sokoto, Nigeria for their kind assistance during the sample analysis. The research received no specific grants 
338

\section{Conflict of Interest}

The authors declare that there are no conflicts of interest related to this article.

\section{References}

Adah MI, Jaji Z, Agwazim BF, El-yuguda AD, Mani AU (2002). Detection of human rotavirus in feces from diarrhoeic calves in north-east Nigeria. Tropical Animal Health and Production 34(1):1-6.

Adah MI, Wade A, Taniguchi K (2001). Molecular epidemiology of rotavirus in Nigeria: detection of unusual strains with G2 P [6 and G8P [1] specificities. Journal ofClinical Microbiology39(11):3969-3975.

Alkali BR, Daneji AI, Magaji AA, Bilbis LS (2015). Clinical symptoms of human rotavirus infection observed in children in Sokoto, Nigeria. Advances in Virology 84909575.

Aminu M, Ahmad AA, Umoh JU, DeWar J, Esona MD, Steele AD (2008). Epidemiology of rotavirus infection in North-western Nigeria. Journal of Tropical Pediatrics 54(5):340-342.

Aminu M, Auwal G, Inabo HI, Esona MD (2014). Prevalence and effect of breast feeding practices on rotavirus infection in children with gastroenteritis in Zaria, Nigeria. Eleventh International Rotavirus Symposium, 3-5 September, New Delhi, India.

Ansari SA, Sattar SA, Springthore VS, Wells GA, Tostowarwk W (1988). Rotavirus survival on human hands and transfer of infections virus to animate and non-porous inanimate surfaces. Journal of Clinical Microbiology 26(8):1513-1518.

Audu R, Aremu Omilabu S, de Beer M, Peenze I, Duncan Steele A (2002). Diversity of human rotavirus VP6, VP7, and VP4 in Lagos State, Nigeria.Journal of Health Population and Nutrition 20(1):59-64.

Bahartha AS, Al Ezzi JI (2015). Risk factors of diarrhea in children under 5 years in Al-Mukalla, Yemen. Saudi Medical Journal 36(6):720-724.

Bass CW, Dorsey KN (2004). Rotaviruses and other agents of gastroenteritis. In: Richard E, Behrman F (Eds). Nelson Textbook of Pediatrics, Raven Press, Philadelphia, USA pp 107-110.

Centre for Disease Control (CDC) (2008). Rotavirus surveillanceworldwide, 2001-2008. Morbidity and Mortality Weekly Report 57:1255-1257.

Dennehy PH (2000). Transmission of rotavirus and other enteric pathogens in the home. Journal of Pediatrics Infectious Diseases 19(10):103-105.

Estes M, Kapikian A (2007). Rotaviruses. In: Knipe D, Howley P, Griffin D, Lamo R, Martin M, Roizman B, Straus S (Eds). Fields' Virology. Wolters Kluwer Health, Lippincott Williams and Wilkins, Philadelphia pp 1917-1974.

Ghosh S, Varghese V, Samajdar S, Sinha M, Naik TN, Kobayashi N (2007). Evidence for bovine origin of VP4 and VP7genes of human group A rotavirus G6P [14] and G10P [14] strains. Journal of Clinical Microbiology 45(8):2751-2753.

Iyoha $\mathrm{O}$, Abioudun PO (2015). Rotavirus genotypes causing acute watery diarrhea among under five children in Benin City, Nigeria. Nigerian Journal of Clinical Practice 18(1):48-51.

Junaidu SA, Umeh C, Olabode AO, Banda JM (2011). Incidence of rotavirus infection in children with gastroenteritis attending Jos University Teaching Hospital, Nigeria. Virology Journal 8(1):233.
Karambu S, Matiru V, Kiptoo M, Oundo J (2013). Characterization and factors associated with diarrheal diseases caused by enteric bacterial pathogens among children aged five years and below attending Igembe District Hospital, Kenya Pan African Medical Journal 16(1):37-43.

Keswick BH, Pickering HL, DuPont HL, Woodward WE(1983). Survival and detection of rotaviruses on environmental surfaces in day-care centres. Applied Environmental Microbiology 46(4):813-816.

Koopmans M, Brown D (1999). Seasonality and diversity of group A rotaviruses in Europe. Acta Paediatrica 88:1419.

Lamberti LM, Walker CLF, Noiman A, Victora C, Black RE (2011). Breastfeeding and the risk for diarrhea morbidity and mortality. BMC Public Health 11(3):S15.

MAWR (2008). Report of the ministry of agriculture and water resources. In: NgamaYL, Bunu Z, Saidu SA (Eds). Proceedings of the Yobe state economic summit. Spectrum Books Limited, Spectrum House, Ring road, Ibadan, Oyo state, Nigeria pp 37-64.

Mwenda JM, Ntoto KM, Abebe A, Enweronu-Laryea C, Amina I, Mchomvu J, ... Steele AD (2010). Burden and epidemiology of rotavirus infection in selected African countries; preliminary results from the African rotavirus surveillance network. Journal of Infectious Diseases 202(1):5-11.

Nair H, Campbell H, ParkJJ, Brondi L, Shi T, Olsson S, ... Kirdos A (2015). Common childhood infections and gender inequalities: a systematic review. UNICEF Publication pp 46.

Nakawesi J, Wobudeya E, Ndeezi G, Mworozi E, Tumwine JK (2010). Prevalence of and factors associated with rotavirus infection among children with acute diarrhea in Uganda. BMC Pediatrics 10(1):69.

Odimayo MS, Olanrewaju WI, Omilabun SA, Adegboro B (2008). Prevalence of rotavirus - induced diarrhea among children under 5 years in Ilorin, Nigeria.Journal of Tropical Pediatrics 54(5):343-346.

Offit PA, Clark MF (2000). Reoviruses. In: Mandel GI, BennettJE, Dolin R (Eds). Principles and practice of infectious diseases. Churchill Livingstone, Philadelphia, USA pp 1696-1703.

Ogunsanya JI, Rotimi VO, Adenuga A (1994). A study of etiological agents of childhood diarrhea in Lagos, Nigeria. Journal of Medical Microbiology 40(1):10-14.

Oruonye ED (2009). Geographical aspects of Yobe state of Nigeria. Afab Educational Books, Shukura House, Katako Junction, Jos, Plateau State, Nigeriapp 45-69.

Pennap G, Peenze I, DeBeer M, Pager CTU, Kwaga JPK, Ogalla WN, ... Steele AO (2000). VP6 sub groung and VP7 serotype of human rotavirus in Zaria. Nigeria. Journal of Tropical Pediatrics 46(6):344347.

Pennap G, Umoh JU (2010). The prevalence of group A rotavirus infection and some risk factors in pediatric diarrhea in Zaria, North central Nigeria. African Journal of Microbiology Research 4(14):1532-1536.

Putt SNH, Shaw APM, Woods AJ, Tyler L, James AD (1987). Veterinary epidemiology and economics in Africa: A manual for use in the design and appraisal of livestock health policy. Department of Agriculture, University of Reading, ILCA Manual No 3, Berkshire, Reading, England pp 27-45.

Quigley MA, Cumberland P, Cowden JM, Rodrigues LC (2006). How protective is breast feeding against diarrheal disease in infants in 1990s England? A case-control study. Archives Diseases of Children 91(3):245-250. 
Sergio JV, Ponce de Leon AA (2009). Analysis of mortality from diarrhea disease in under five children in Brazil cities with more than 150,000 inhabitants. Cadernos deSaude Publica 25(5):1093-1102.

Sherchand JB, Haruki K (2004). Rotavirus infection in children and animals of urban and rural Nepal. Journal of Nepal Health Research Council 2(1):1-4

Steele AD, Nimzing L, Peenze I, deBeer MC, Geyer A, Angyo, ... Gomwalk NE (2002). Circulation of the novel GP and G8 rotavirus strains in Nigeria in 1998/1999.Journal of Medical Virology67(4):608-612.

Tate JE, Burton AH, Boschi-Pinto C, ParasharUD (2016). Global, regional and national estimates of rotavirus mortality in children $<5$ years of age, 2000-2013. Clinical Infectious Diseases 62(S2):S96-105.

Thrusfield M (1997). Veterinary epidemiology. $2^{\text {nd }}$ edition, Blackwell, 18 Cowley Road, Oxford pp 183-187.

Waggie Z, Hawkridge A, Hussey GD (2010). Review of rotavirus studies in Africa: 1976-2006. Journal of Infectious Diseases 202(1):23-33.
White LJ, Buttery J, Coope B, Nokes DJ, Medley GF (2008). Rotavirus within day-care centres In Oxfordshire, UK: characterization and partial immunity. Journal of Royal Society 5(29):1481-1490.

WHO (2009).Manual of rotavirus detection and characterization methods: Immunization, Vaccines and Biologicals.2009:WHO/IVB/08.17.

WHO (2013). Estimated rotavirus death for children under 5 years of age: Global immunization news. Retrieved June 6, 2016 from https://www.who.int/immunization/monitoring_surveillance/burden /estimates/rotavirus/en/.

Yilgwan CS, Okolo SN (2012). Prevalence of diarrhea disease and risk factors in Jos University Teaching Hospital, Nigeria. Annals of African Medicine 11(4):217-221. 